Robert Dion

\section{Des fictions sans fiction ou le partage du réel}

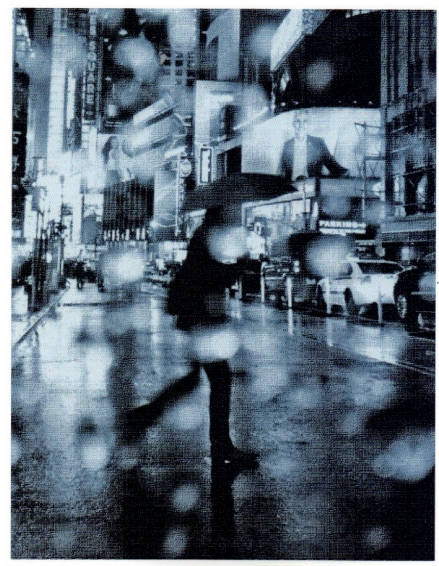

Les Presses de l'Université de Montréal

\section{DION, Robert. Des fictions}

sans fiction ou le partage du

réel. Montréal: Les Presses de

l'Université de Montréal, 2018.

Collection Espace Littéraire.

\section{2p. ISBN 978260638433}

Zilá Bernd $^{1}$

Recebido em 3 e aprovado em 7 de junho de 2018.

Robert Dion (1962-) é professor

do Departamento de Estudos Literários da

Université du Québec à Montréal, membro do grupo de pesquisas interuniversitário sobre a literatura e a cultura quebequense
(CRILCQ) e crítico literário com grande número de obras publicadas, destacandose os estudos sobre ficção e autoficção. Robert Dion esteve no Brasil, na Universidade Federal Fluminense (UFF) e na Universidade Federal do Sul (UFRGS), há alguns anos atrás quando estava em vigor o acordo de cooperação internacional Quebec/UFF/UFRGS.

Conforme o autor, o desafio para fazer essa reflexão sobre a inscrição do real na ficção nasceu de uma pergunta de sua filha de 8 anos: "por que a abelha queria me picar?" ao que ele respondeu que não sabia. Então a menina lançou-lhe o desafio: "Então invente, mas diga algo de verdadeiro!" Considerou então que o desejo da filha não supunha nenhuma incompatibilidade entre a invenção e a verdade, fato rememorado pelo autor na abertura desse livro.

Nesse seu mais recente livro, o autor aborda o tema que, segundo ele, vem constituindo tendência da literatura mundial na contemporaneidade: as ficções sem ficção ou a partilha do real. Dizendo de outra forma: o autor aborda a tendência cada vez maior de incluir, em obras de ficção, elementos da realidade, sendo a problematização dessa questão o tema fulcral da obra em apreço. 
Para ilustrar sua tese desta "fome de real" na contemporaneidade, Robert Dion apresenta estudos de destacados autores em sua maioria francófonos como Yannick Haenel (nascido na França em 1967, Prêmio Médicis), Louis Hamelin (nascido em 1959, no Quebec), Hélène Fréderick (nascida no Quebec em 1976), Carl Leblanc (cineasta-documentarista e escritor), Éric Plamondon (nascido em 1969, no Quebec) e Régis Jauffret (nascido em 1955, na França, prix Gouncourt), incluindo o autor de origem alemã W. G. Sebald (nascido em 1944 na Alemanha) e acrescentando ainda um capítulo (VII) sobre a coleção "L'un et l'autre" (edições Gallimard), além de uma conclusão.

Entre os romances analisados estão Les émigrants (1992), de W.G. Sebald, (cap. I); Jan Karski (2009) de Yannick Haenel, pseudônimo de Jean Deichel (cap. II); La constellation $d u$ lynx (2017, de Louis Hamelin), La Poupée de Kokoshka (2010) e Forêt contraire (2014) de Hélène Frédérick (cap. III) . O capítulo IV analisa uma série de documentários de Carl Leblanc e o V apresenta um estudo de várias autobiografias de Eric Plamondon. Claustria, de Jauffret, é analisado no capítulo VI, ficando o capítulo VII reservado ao estudo de obras da Coleção $L^{\prime} u n$ et l'autre, da editora Gallimard (França).

Vale aqui uma citação do autor na introdução do livro: «Dans 1'optique qui est la mienne, en effet, il s'agit de considérer 'le réel' par ses 'données' qui se situent hors de la fiction - personnes ayant réellement existé, archives et documents, etc. - et qui, dès qu'elles se trouvent mis en récit, acquièrent un double statut - factuel et fictionnel - complexifiant l'interprétation $»^{2}$ (p. 14). Reescrevendo o real na ficção, quebra-se o estatuto ficcional que estabelece a clivagem entre o verossímil e o romanesco, o documental e o ficcional.

A etiqueta de "ficções do real" pode parecer oximórica, mas é esse o escopo do livro que analisa diferentes romances de sete diferentes autores para refletir sobre os modos de inscrição do real na ficção, sobre as relações com o real ou ainda sobre as estratégias formais e éticas destas relações. Para proceder à leitura destas ficções do real, o autor considera três pontos de vista: a pessoa, a história e a crônica jornalística. $\mathrm{O}$ que se percebe nos romances dos escritores analisados são formas híbridas que associam a questão da pessoa e da história ao documentário e à ficção. 
Se o real sempre se fez presente nas obras de ficção, talvez as fronteiras entre ficção e não ficção nunca tenham sido tão problematizadas como nos romances contemporâneos, escritos em geral por autores jovens como os que constituem o corpus de Robert Dion. Todos os autores evocados reivindicam uma verdade ou um saber sobre o real. Fazer coabitar ficção e fatos comprovados faz com que todos os escritores analisados se situem simultaneamente na literatura e fora dela, apontando para a porosidade das fronteiras entre o que procede de fatos e o que é da ordem do discurso e da ficção.

\section{Notas}

1 Professora do Mestrado em Memória Social e Bens Culturais do Unilasalle, Canoas, Rio Grande do Sul. Pesquisadora 1b do CNPQ. zilabster@gmail.com .

2 Na minha ótica, efetivamente, trata-se de considerar 'o real' por seus 'dados' que se situam fora da ficção - pessoas que realmente existiram, arquivos e documentos, etc. - e que, desde que se encontram narrativizados, adquirem um duplo estatuto - factual e ficcional - complexificando a interpretação. Traduçao da resenhista. 